first clinical trial. True to form it is reprinted in the turgid prose of the New English Bible. However, the modern interest in the ethics of human experimentation dates from the Nazi concentration camps, and the legacy of Nuremberg permeates this volume. Robert Massey puts the history of experimentation in cultural context and cautions us against the use of the retrospectoscope in judgement. Engelhardt argues fairly cogently that randomised clinical trials are not intrinsically unethical, comparing the patient who consents to enter one with the man who joins a poker school and thereby agrees to have his fellow players attempt to deceive him. Unfortunately, this essay like many in the volume assumes a familiarity with the work of Hans Jonas. I would strongly advise anyone who is unfamiliar with it not to bother with this book.

Spicker argues against randomised trials before pilot trials have set out the ground rules - all very sensible. The essay by Michael Ruse on interrupting clinical trials is the first statistical paper in the volume and the first one I really warmed to.

Is there an obligation to participate in biomedical research? Arthur Copplan makes the (theological) point that to be the recipients of the benefits of someone else's sacrifice does not make us debtors. We are only obliged to be grateful, not to sacrifice ourselves.

The Dagis caution us against autoexperimentation, and Ladimer reduces the harm done by experiments to mere money.

This really is the sort of book that you only read because you've been asked to review it.

PROFESSOR T J HAMBLIN Professor of Immunohaematology Southampton University 15 Queens Park South Drive Bournemouth

\section{The Nazi Doctors}

Robert Jay Lifton, 561 pages, London, $£ 9.95$, Papermac, a branch of Macmillan, 1987

This long and important book is divided into three parts. Part I, Life Unworthy of Life, is basically about eugenic euthanasia, and recounts how in this field, before proceeding to the next step - the Nazi extermination of Jews and other groups such as gypsies - doctors were involved at all stages of the euthanasia project.
Part II, entitled Auschwitz, the Racial Cure, consists of detailed accounts of interviews with many of the doctors who themselves were Nazis, and who, often by means of slow induction into the lethal system, became adapted to it. They did so in various ways, some being totally involved in an almost religiously fanatical way with the aim of cleansing and perfecting the German people. This was completely in line with Hitler's dream as stated in Mein Kampf and repeated many times thereafter. Some doctors carried out their tasks, which led to the deaths of innumerable humans with less than relish, while others were able to be relatively kind and overtly healing but always within the general ambience of 'licensed mass murder' on a mega-scale. The author calls this duality, this polarisation, 'doubling' by the doctors into twin selves, a sort of Dr Jekyll and Mr Hyde effect. Dissociation or splitting was responsible for this. Seriously disturbing though all the book is, one of the most worrying parts is the way in which some of the prisoner-doctors called upon - or 'privileged' - to help in the camp, were drawn into the vortex of the Racial Cure, which consisted of the most massive genocidal organisation the world has ever known.

Thus, some of the prisoner-doctors, while remaining concerned with being healers in one way, suffered from doubling too, so that they could cooperate in the lethal project with their 'other selves'. This had an element of self-preservation in it, but the situation was more complicated than that. It shows the power of the group, and the institutional dynamics of an extermination camp.

Part III, The Psychology of Genocide, is much shorter than Part II, but is the most interesting part of the book. A part of each doctor who eventually became adapted to the Auschwitz ethos did so at the cost of part, or in some cases nearly all, of his basic humanity. This involved a breakdown of the balance of life and death instincts within him, with a massive bias towards death. Identification with the aggressor in the interests of self-preservation was the general reaction. When these medical staff members were so reacting, preserving the self was accomplished for the time being by a massive putting of death into the concentration camp inmates; it was they, the inmates, who were killed, not the doctor's own 'self', and the process was repeated many, many times upon a succession of victims.

In order to make this abattoir of humanity efficient in carrying out the $\overrightarrow{\bar{D}}$ most grisly of work, the inmates were herded, de-humanised by brutal $\Rightarrow$ treatment, including hard physical of work and gross starvation, so that theyo were helped to be less than human $\frac{C}{0}$ before they were killed. This facilitated $\overline{\bar{\omega}}$ the killing of them so that it could be $\overrightarrow{\widetilde{D}}$ fitted loosely into the euthanasia $\propto$ project. The doctors tried to make their कै role have some compatibility with their $\vec{O}$ Hippocratic oath, some conformity with it, but it was an unconvincing and $\overrightarrow{\vec{\omega}}$ dishonest self-protecting edifice of $\stackrel{\vec{\omega}}{ }$ confused rationalisation. In order to $\overrightarrow{3}$ carry on, the phenomenon labelled by $\Phi$ the author as 'doubling' took place. $\vec{G}$ Thus, the doctor was split and polarised into a reasonably compassionate and ir genial self, the Dr Jekyll self, and the $\vec{d}$ Nazi officer caught in the machine of mass murder, became the Mr Hyde character. The whole rationale of The $\vec{T}$ Final Solution, and prior to that of the 'this person is not fit to live' of the euthanasia campaign, appears to be based on the projection of all the $\vec{\varphi}$

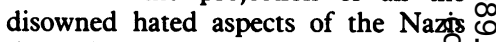
themselves, into victims labelled Jewor gypsies, mentally subnormals psychotics, and there and then was tit slaughter: they were killed. I am reminded of the factors that I and others $\varrho$ have found in the minds of multiple $\subseteq$ murderers. In Auschwitz the situation $\overrightarrow{\vec{A}}$ was highly organised on a colossal scale. The most horrendous feature of it was a combination of a confused racial selfidealisation, with a massive denigration of categories of people designated as suitable only for extermination, and the efficient carrying out of the programme of annihilation.

Everyone should read this book and $\delta$ face the painful question: 'How would I 3 have behaved as a doctor in Auschwitz, 웅 and how would I have behaved as a prisoner-doctor?’

ARTHUR HYATT WILLIAMS, N Consultant, Camden Psychotherapy Unit, ㅇ Medical Psycho-analyst $\omega$

Health and Medicine
in the Islamic
Tradition

Fazlur Rahman, 150 pages, New York, $\stackrel{\mathbb{Q}}{\varrho}$ $\$ 18.95$, Crossroad Publishing Co, 1987.

There are six major religions in the 
world: three started in India Hinduism, Buddhism and Sikhism and three began in the Arab countries Judaism, Christianity and Islam. The second largest religion in Britain, and in the Soviet Union, is Islam. In his foreword to this book, Martin Marty points out that if present trends continue, before many decades pass, Muslims will outnumber Jews to become the second largest faith group in the United States. It is true that the Muslim faith has generated a world. In 1950 , every seventh human in world was Muslim and in 1985, every fifth human followed Islam or bore its name.

Islam, like other religions, exerts its hold because it addresses, and in many ways satisfies, the longings and desires of the people for experience, authority and identity. This book shows how extensive is the reach of the Islamic faith into the dimensions of private and public life, and the chapter on medical ethics reveals how Islam pays attention to detail in doctor-patient relationships. I agree with Professor Rahman when he speaks of his book as the first of its kind in the English language. It may surprise the reader to learn how profound, elaborate and intricate are the elements of Islam that have a bearing on health and medicine. The Holy Qur'an, the treatises from various Muslim sects, the stories attributed to the career of the prophet Mohammed, and other elements of tradition are cited in this book in order to relate the Muslims' search for well-being to the allimportant demand that they follow the Will of God - Allah!

Seven compact chapters deal with: An historical introduction to Islam; Well-being and illness in the view of the Islamic world; The religious values of medicine; Prophetic medicine; Islamic medical care; Medical ethics, and the Islamic concepts of birth, abortion, contraception, sexuality and death. The Epilogue is followed by a list of references and name/subject indexes. Each chapter tells a different story and each story is told with a modern scientific analogy, where possible. This book is for a serious reader or a student of theology and medical ethics. NonMuslims, Westernised Muslims and devout Muslims - looking from different angles - will find considerable valuable information on health, medicine and Islam in this book.

Islamic views on medical ethics are put in a nutshell, with didactic statements, in a chapter which has four sections:- Doctor/patient relationships; Human dignity; The family, and Bioethical issues (for example, organ transplantation, anatomical dissection, genetic engineering, test-tube babies and prolongation of life). These matters are discussed in the light of Islamic teachings, with references to the work of eminent Muslim physicians such as Al-Razi, Nizami and Ibne-Sina. An example of the way one issue is handled: Should a doctor charge a fee, and if so, how much? According to the Prophetic Hadith, it is lawful to pay a physician for his medical services. Al-Ruhavi, the work of Ishaq-ibne-Ali, states that a doctor should earn enough to alleviate the necessity of doing other work, to afford marriage and to raise children, (educating them in the art of medicine) and to lead a comfortable family life. It also suggests that the rich should pay the physician generously so that he can look after the medical needs of the poor without charge. If the rich do not do so, physicians would be forced to give up their medical work and follow some other profession, as a result of which rich and poor alike would suffer. This practice was largely followed by mediaeval physicians in Islam in their private clinics, but not in local free hospitals.

I recommend this book to every doctor who has Muslim patients on his or her list and everyone interested in the Islamic aspects of medical ethics. It is a good buy for every medical library, at home or abroad.

BASHIR QURESHI, General Practitioner 32 Legrace Avenue, Hounslow West, Middlesex TW4 7RS

\section{Efficiency and the NHS: A Case for Internal Markets}

\section{Ray Robinson, 40 pages, London, $£ 4.50$, the IEA Health Unit, 1988.}

This most provocative paper by a member of the King's Fund Institute gives an analysis of the proposal to introduce an internal market to the National Health Service (NHS). So far 'the Thatcher Government's strategy has been to retain the NHS's traditional structure while attemping to increase the efficiency with which the taxpayer's money is used'. As another step the Government has been urged (first by Professor Enthoven of Stanford University) to introduce an internal market in the NHS. According to
Enthoven the NHS needs incentives for increased efficiency: 'It relies on dedication and idealism. It offers few possible incentives to do a better job'.

An internal market would 'seek to organise the trade (of buying and selling services between District Health Authorities (DHAs)) on a systematic basis', where 'each DHA would receive a per capita cash allocation similar to its present RAWP allocation'. DHAs would be paid for services to outsiders and they would also control patient referrals to providers (both NHS and private) outside the districts and would pay for them, 'consultants' contracts would be held at district level and family practitioners would have contracts with DHAs'.

The main part of the paper is an assessment of how an internal market would increase efficiency. The author identifies four sources of potential gain. According to advocates of internal markets, competition is a way of reducing inefficient use of resources: $x$-inefficiency. DHAs would compete for patients, their revenue would partly depend upon their success in doing so. The problem with this suggestion is as the author says 'the level of efficiency in any unit depends upon the ability of management to eliminate waste'. As 70 per cent of NHS costs is labour and a large part of that is doctors' and nurses' wages, in order to increase efficiency greatly managers must improve the efficiency of the work of doctors and nurses. 'It is not clear how exactly competition would spur consultants to work more efficiently'. Also 'This (proposal) would represent a considerable restriction of GPs' existing freedom of referral'. Again it is not clear how this would work, but 'many GPs already refer the majority of their patients to local hospitals and so a "limited list" might not constitute such a large change' and 'Enthoven proposes that GPs' contracts should be held by districts'. This sounds threatening, but what is not discussed in the paper is how managers would decide where to place their contracts, and presumably that would be guided by professional advice and indeed practice.

Also 'a crucial feature of a competitive market is that there should be freedom of entry and exit'. So 'new investment would be required in those districts gaining patients while excess capacity existed elsewhere' but 'it is not clear that a government would be willing to build new capacity while there is excess capacity elsewhere'. There would be a similar problem with labour. The proposal would also mean 